\title{
Создание фотослоя на основе селена с помощью импульсного отжига
}

\author{
А.Н. Папантонопуло ${ }^{1,2)}$, Ф.В. Тихоненко ${ }^{2)}$ \\ ${ }^{1}$ Новосибирский государственный технический университет, Новосибирск, \\ 630073, Карла Маркса проспект, 20 \\ ${ }^{2}$ АО «НПП «Восток», Новосибирск, 630049, Дуси Ковальчук, 276 \\ эл.noчma: artem.papantonopulo@yandex.ru, tihonenko@nzpp.ru
}

DOI 10.34077/RCSP2019-23

В данной работе была исследована возможность создания фоточувствительных структур ИКдиапазона на основе кремния, легированного селеном свыше предела растворимости (hyper doped silicon). Полученные результаты могут быть использованы в солнечной энергетике, а также для создания фотоприёмных устройств ИК-диапазона.

В настоящее время тепловизионные системы ИК-диапазона получили широкое распространение в медицине, автомобильной промышленности, строительстве и т.д. Основой для создания фотонных детекторов служат соединения $\mathrm{A}^{\mathrm{III}} \mathrm{B}^{\mathrm{V}}$ и $\mathrm{A}^{\mathrm{II}} \mathrm{B}^{\mathrm{VI}}$, в то время как для тепловых детекторов используют материалы с высоким температурным коэффициентом сопротивления. И то, и другое создаёт определённые технологические трудности при интеграции фоточувствительных элементов с электронной схемой управления и усиления, выполненной по традиционной кремниевой технологии. В то же время, использование кремния для детектирования ИК-излучения затруднительно, в силу его большой ширины запрещенной зоны.

Расширить диапазон поглощения кремнием ИК-излучения возможно, например, за счёт примесного поглощения, для чего необходимо легирование кремния примесями, образующими глубокие уровни [1]. Одним из наиболее подходящих для данных задач элементом является селен за счет большого сечения фотоионизации и низкого сечения захвата. Однако селен имеет достаточно низкий предел растворимости в кремнии и высокий коэффициент диффузии. Первое снижает максимально достижимый квантовый выход, а второе ограничивает плотность фоточувствительных элементов.

Решить обе этих проблемы можно, используя для формирования фоточувствительного слоя быстрый термический отжиг. При этом удаётся сформировать субмикронные легированные слои с концентрацией селена, превышающей предел растворимости [2].

Была отработана технология импульсного отжига для создания фоточувствительного слоя на основе селена. Структура и состав полученных слоёв контролировались с помощью рамановских спектров и спектров поглощения. Концентрация свободных носителей определялась с помощью вольт-фарадных характеристик и эффекта Холла. Фотоэлектрические свойства слоя были исследованы при 77К на фотосопротивлениях и фотодиодах. Результаты подтверждают возможность создания фоточувствительных структур ИК-диапазона на основе кремния, легированного селеном свыше предела растворимости.

\section{Лumepamypa}

[1] Si H. Pan, Daniel R. et al. Enhanced visible and near-infrared optical absorption in silicon supersaturated with chalcogens. Appl. Phys. Lett. 98, 121913 (2011).

[2] Berencén, Y. et al. Room-temperature short-wavelength infrared Si photodetector. Sci. Rep. 7, 43688

(2017). 